Article

\title{
Thermal and Catalytic Cracking of Toluene Using Char from Commercial Gasification Systems
}

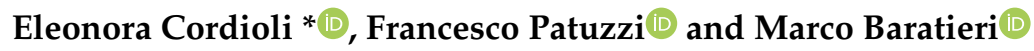 \\ Faculty of Science and Technology, Free University of Bolzano, Piazza Università 5, 39100 Bolzano, Italy; \\ francesco.patuzzi@unibz.it (F.P.); marco.baratieri@unibz.it (M.B.) \\ * Correspondence: ecordioli@unibz.it
}

Received: 3 September 2019; Accepted: 25 September 2019; Published: 1 October 2019

\begin{abstract}
Tar formation hinders the development of biomass gasification technologies. The use of pyrolytic char as a catalyst for removing tar has been widely investigated; its large specific surface area and pores distribution make it a good candidate for the cracking of heavy hydrocarbons. The present work assesses the catalytic activity of char from a commercial gasifier. Thermal degradation tests in $\mathrm{N}_{2}$ and in $\mathrm{CO}_{2}$ proved that the char is suitable for high-temperature applications (catalytic cracking) and showed release of $\mathrm{CO}$ and $\mathrm{H}_{2}$, which might affect the catalytic performance of the char when used for tar removal applications. For inspecting the potential of the char for tar removal, toluene was chosen as model tar. Through GC-FID, toluene removal efficiency and the amount of benzene produced from its decomposition were evaluated. Tests up to $1273 \mathrm{~K}$ resulted in tar removal efficiencies as high as $99.0 \%$, and empty reactor tests allowed for discerning the effects of thermal and catalytic cracking. The catalytic activity of the char was more pronounced at $1173 \mathrm{~K}$, as char increased the toluene removal efficiency from $39.9 \%$ (empty reactor) to $60.3 \%$. The results confirmed that gasification char, like pyrolytic char, has a high potential for catalytic tar removal applications.
\end{abstract}

Keywords: gasification char; thermal degradation; tar removal; catalytic cracking; toluene

\section{Introduction}

The formation of tar during gasification of biomass is still a major hindrance for the development and application of gasification technologies on a wide scale. The condensation of tar typically starts to be significant at temperatures lower than $573 \mathrm{~K}$ and can damage the process equipment, because, as it condenses, tar becomes very viscous and sticky, blocking pipelines, engines, fuel lines, and nozzles. Also at temperatures above $673 \mathrm{~K}$, the tar can cause severe problems since it can undergo reactions that lead to formation and deposition of coke, which further causes fouling and plugging of the equipment components [1]. For this reason, the tar level requirements can be very strict, but they depend on the end-use application of the producer gas obtained from the gasification of biomass. For use in internal combustion engines, for instance, the tar content in the gas should not exceed $100 \mathrm{mg} / \mathrm{m}^{3}$, while for use in gas turbines the limit set is at a much lower $5 \mathrm{mg} / \mathrm{m}^{3}[2,3]$. This is because, although in turbines the gas temperature is usually very high and tar is in the gaseous form, turbine blades are very sensitive to coke deposition issues [3-5]. For use in fuel cells, some research studies have reported that solid oxide fuel cells (SOFCs) can tolerate more than $10 \mathrm{mg} / \mathrm{Nm}^{3}$ of $\operatorname{tar}$ [6], but further research is required to establish the gas quality requirements not only for SOFCs but also for other types of fuel cells [7]. With regards to the use of producer gas for the production of methanol or synthetic diesel through Fischer-Tropsch (FT) synthesis, Tijmensen et al. [8] recommend the complete removal of tar. In fact, tar condensation can form a sticky film on the surface of the catalyst used in the FT process, blocking its active sites, and compromising its activity. 
Several technologies have been developed and implemented for producing high-quality gas with low levels of tars and other contaminants. Generally, the gas cleaning processes are classified as cold gas cleaning or hot gas cleaning. Cold gas cleaning includes dry gas cleaning (cyclones, electrostatic precipitators, rotating particle separators, bag filters, ceramic filters, and absorbers) and wet gas cleaning (spray towers, impingement scrubbers, venture scrubbers, wet cyclone, wet electrostatic precipitators, and packed column scrubbers) $[9,10]$. Hot gas cleaning can be conducted either by physical filtration, which is inefficient by itself or by conversion of tar into lighter, non-condensable gases $\left(\mathrm{H}_{2}\right.$ and $\left.\mathrm{CO}\right)$ through thermal or catalytic cracking [11-13]. Given the high temperatures required for reaching high cleaning efficiencies with thermal cracking (typically ranging from $1273 \mathrm{~K}$ to $1573 \mathrm{~K}$ ), this option is not always feasible or convenient. Catalytic cracking, on the other hand, is very effective at temperatures lower than $1273 \mathrm{~K}$ and allows for the retrieval of chemical energy through the efficient conversion of tar into useful products. Numerous studies have investigated and demonstrated the high effectiveness and efficiency of catalysts such as dolomites, olivines, alkali and alkaline earth salts, Fe or Ni-based catalysts [14-18]; however, these can be very expensive or require frequent regeneration. In recent years, char obtained from pyrolysis or gasification of biomass has been investigated for its potential use in gas cleaning applications as adsorbent, catalyst, or catalyst support [19-21]. Its specific characteristics, especially its micro-porous structure and large specific surface area [22], but also the presence of alkali and alkaline earth metallic (AAEM) species and O-functional groups on its surface [23,24], make char a suitable material for tar adsorption or catalytic cracking [25-29]. Buentello-Montoya et al. [30] reviewed the possible application of gasification char as the catalyst for tar reforming. Nevertheless, most of the cited research has been testing either charcoal or biomass char produced from pyrolysis under controlled operating conditions. Pyrolysis and gasification chars show different textural and chemical properties, hence it is of interest to evaluate also the performance of gasification chars, which show higher surface areas and higher ash contents compared to pyrolytic chars [31]. Ravenni et al. [32] tested char from a pilot gasifier for adsorption and reforming of toluene and naphthalene in the temperature range $250-800^{\circ} \mathrm{C}$. Choi et al. [33] tested partially $\mathrm{CO}_{2}$-gasified char from lignite to decompose benzene at $900^{\circ} \mathrm{C}$. In both cases, it was shown that char from gasification processes could be particularly suitable for catalytic tar removal applications at temperatures of $800{ }^{\circ} \mathrm{C}$ and above.

To the knowledge of the authors, no study has tested biomass char obtained from an actually operating gasifier. All the cited literature concerning biomass char has used either pyrolysis char or gasification char produced under controlled conditions in lab-scale or pilot-scale gasifiers. The study presented in this work was carried out on char samples that have been collected from a commercial gasification plant currently operating in the province of Bolzano (South Tyrol, Italy). In this region, more than 40 small-scale gasifiers were installed in the last years, in most of the cases integrated into small or micro-district heating grids. Indeed, small-scale gasification of woody biomass is a technology that has had a rapid development, especially in recent years, mainly driven by favorable subsidization regimes [34]. The char produced in these plants presents chemical and physical characteristics that make it a potentially interesting and valuable product in the view of pushing gasification from a co-generative process to a poly-generative platform [35], but economically viable solutions are not available yet, and the disposal of char still constitutes a non-negligible cost for plant owners [36].

The aim of the present work is to repurpose the char produced in one of these commercial gasification plants and to investigate an alternative valorization route for a product that is now treated as a waste and represents a cost in the management of the plant. In particular, the collected gasification char has been studied as a catalyst for the decomposition of a model tar compound (toluene), and hence as a filtering medium to be used for producer gas cleaning. The char has been taken as it is, as a by-product and a waste, and studied as received, without any further activation. On the one hand, this means that every batch of char collected might have slightly different properties (it is hence very important to make a preliminary study for determining the physical and chemical characteristics of the char if a new batch is used). On the other hand, in a real application of char for gas cleaning purposes, this is what would be done for convenience. The char discarded in the gasification 
process would be taken and be directly used as a tar removal filter for the producer gas. The aim of this study is indeed to prove that gasification char, as it is, is reactive enough to be used for such applications. In this sense, finding ways to reuse or recycle the char would positively affect the overall process and the overall efficiency of gasification plants from both the energetic and the economic point of view.

\section{Materials and Methods}

The char used for the work hereby presented was collected from a small gasification plant located in South-Tyrol (Italy), with a nominal electric power output of $50 \mathrm{~kW}_{\mathrm{el}}$ and a nominal thermal power output of $80 \mathrm{~kW}_{\mathrm{th}}$. The system is a dual-stage commercial gasifier that consists of a primary pyrolysis stage followed by the main reactor, where gasification takes place. An auger conveyor takes the biomass feedstock (woodchips) into the main reactor, while pyrolyzing it, reaching a maximum temperature of approximately $973 \mathrm{~K}$. In the main reactor, the gasification stage takes place at a temperature of $1173-1223 \mathrm{~K}$. The gasifying agent is air (with an air-fuel equivalence ratio of 0.25 ) and it is introduced in the oxidation zone where the temperature can exceed $1273 \mathrm{~K}$; the producer gas is collected from the top of the reactor and prior to cooling and filtering it is used for the heating of the feedstock conveyor, thus sustaining the pyrolysis stage.

Regarding the characterization of the char collected from the plant, the elemental composition (carbon, hydrogen, nitrogen, and sulphur content) and the ash content, as well as its specific surface area and pore volume, are available from a previous study [22]. The moisture content was determined according to the Standard UNI EN 14774. In addition to this, information about the mineral composition of the ash of the char was determined by means of inductively-coupled plasma optical emission spectroscopy (ICP-OES, Arcos Ametek Spectro, Kleve, Germany).

Two types of tests were considered in the present work in order to assess the suitability of the selected char for catalytic cracking purposes. Firstly, thermal degradation tests were performed to verify the stability of the char at high temperature and to observe any gaseous release from it during the heating process. Secondly, the activity of char for tar cracking was tested using toluene as a representative tar compound.

Thermal degradation tests with the selected char were performed as part of a previous work that focused on the modelling of char degradation through thermogravimetric analyses [37]. The present work concentrates on the overall carbon conversion of the char during the thermal degradation process and on the evolution of the outlet gas composition. The reactor used for the tests is a lab-scale tubular fixed-bed reactor made of stainless steel and installed in the Bioenergy \& Biofuels Laboratory at the Free University of Bozen-Bolzano. Tests have been run in the temperature range 973-1173 K, in order to evaluate the stability of the selected char at these high temperatures and to observe its behavior in terms of gases produced during its thermal degradation. Either pure nitrogen $\left(\mathrm{N}_{2}\right)$ or pure carbon dioxide $\left(\mathrm{CO}_{2}\right)$ was used to feed the reactor. The volumetric flow was equal to $0.06 \mathrm{~m}^{3} / \mathrm{h}$ and was kept constant throughout the experiments. Pure flows were used in order to estimate the char thermal degradation in pyrolysis conditions (pure $\mathrm{N}_{2}$, lowest conversion expected) and in a reactive atmosphere $\left(\mathrm{CO}_{2}\right.$, higher conversion). The setup used for the tests is depicted in Figure 1.

The operating conditions applied for the thermal degradation tests are herein recalled. Approximately $25 \mathrm{~g}$ of char sample was placed inside the reactor above a bed of quartz wool in order to keep the char bed at the mid-height of the reactor, where the furnace temperature is uniform. Then, keeping the flow of the feed gas constant, as in the outlet flow no more oxygen was detected, the heating of the furnace was started at a rate of $10 \mathrm{~K} / \mathrm{min}$ from ambient temperature to a maximum temperature of either $973 \mathrm{~K}$ or $1173 \mathrm{~K}$. This temperature was kept for $5 \mathrm{~h}$ before letting the furnace cool down to ambient temperature again. The temperature within the char bed was monitored throughout the tests by means of a K-type thermocouple. Moreover, the weight of the char sample placed inside the reactor was taken before and after each experimental test, so that the char overall decomposition could be determined in terms of mass loss. The thermal degradation of the char was calculated 
as the percentage of the mass loss during the test, with respect to the initial mass of the sample. Moreover, throughout the tests, the composition of the gas exiting the fixed-bed reactor was analyzed by means of a gas chromatograph (3000 micro-GC, Agilent Technologies, Santa Clara, CA, USA) equipped with a MolSieve $5 \AA$ column (Agilent Technologies) for the detection of $\mathrm{H}_{2}, \mathrm{~N}_{2}, \mathrm{O}_{2}, \mathrm{CO}$, and $\mathrm{CH}_{4}$, and a PoraPLOT $\mathrm{U}$ column (Agilent Technologies) for the detection of $\mathrm{CO}_{2}, \mathrm{C}_{2} \mathrm{~S}, \mathrm{C}_{3} \mathrm{~s}$, and $\mathrm{H}_{2} \mathrm{~S}$.
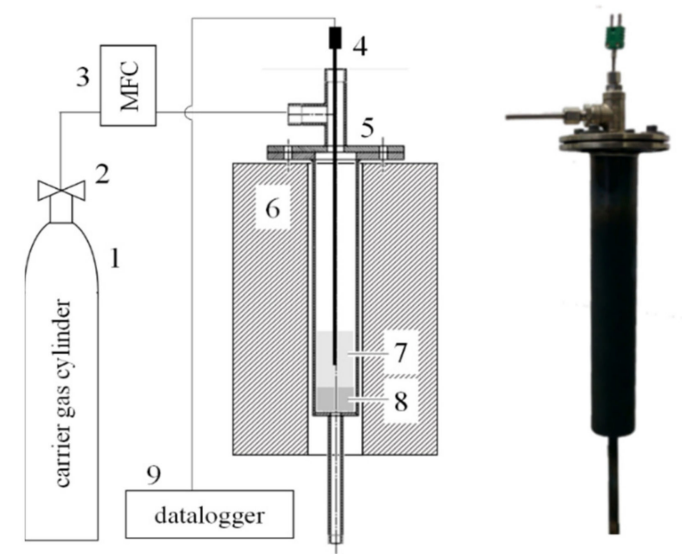

Figure 1. Fixed-bed reactor apparatus for thermal degradation tests. 1. Carrier gas cylinder $\left(\mathrm{N}_{2}\right.$ or $\mathrm{CO}_{2}$ depending on the test). 2. Pressure reducer. 3. Mass flow controller. 4. K-type thermocouple. 5. Reactor. 6. Electric furnace. 7. Char bed. 8. Quartz wool. 9. Data logging system.

The tar cracking tests were performed in a newly designed testing apparatus, in which char is studied as a filtering bed for removing tar compounds from the main gas flow, by means of catalytic cracking mechanisms. The scheme of the test rig is depicted in Figure 2. The main part of the system is a quartz tubular reactor that houses the bed of char and works as a catalytic reactor. The tube has an internal diameter of $40 \mathrm{~mm}$ and is $500 \mathrm{~mm}$ long, and quartz was chosen in order to avoid any chemical interaction between the reactor material and the char bed. The quartz tube is inserted in a steel tubular reactor of slightly larger diameter in order to withstand the local pressures that could arise within the reactor during the tests. A tubular electrical furnace was used to heat up the reactor. Inside the quartz tube reactor, approximately $0.6 \mathrm{~g}$ of char was placed for each test. Quartz wool was used below and above the bed of char in order to support it and to distribute the gas and the heat flow homogeneously through the material. The main feed to the reactor is a flow of $\mathrm{N}_{2}$ equal to $0.03 \mathrm{~m}^{3} / \mathrm{h}$ that is regulated by means of a mass flow controller and in which a specific amount of toluene is injected through a syringe pump (Nemesys, CETONI, Korbussen, Germany) that continuously delivers the liquid to the main gas line. The tubing connecting the nitrogen line to the reactor, including the port where the syringe pump is connected, was wrapped with a heating tape that was kept at a temperature higher than the evaporation temperature of the injected tar compound. In this manner, toluene could evaporate and homogeneously mix with $\mathrm{N}_{2}$ before entering the catalytic reactor. Toluene was chosen as model tar compound as representative of alkylbenzenes [38]. Since toluene has a boiling point of approximately $384 \mathrm{~K}$, a temperature above $473 \mathrm{~K}$ was kept in the gas feed pipes, to make sure no condensation would occur during the injection into the reactor.

At the outlet of the reactor, the product gases pass through a series of impinger bottles filled with isopropanol in order to condense and collect all the tar compounds exiting the reactor, according to the European standard for tar sampling and analysis CEN/TS 15439 (tar protocol). Analyzing the condensed products by means of a GC equipped with flame ionization detector (7890B GC-FID System, Agilent Technologies), the collected toluene and other condensables could be identified and quantified. 


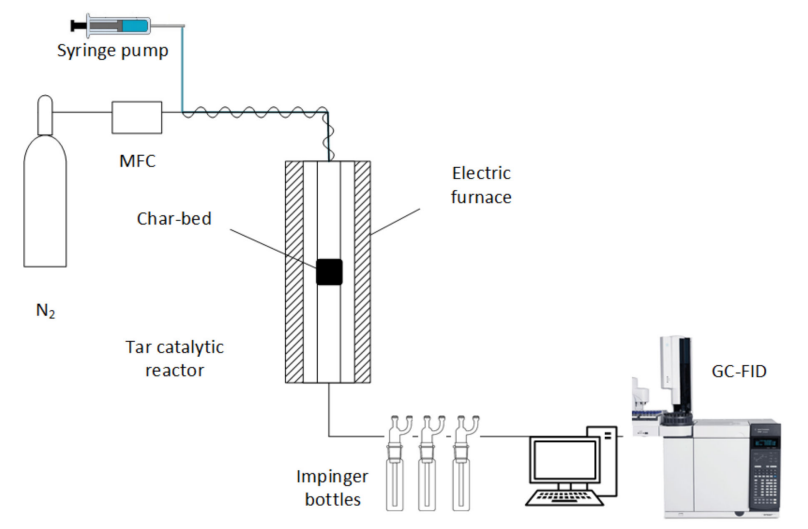

Figure 2. Scheme of the catalytic reactor setup used for testing the adsorption and catalytic activity of char.

Blank tests in pure $\mathrm{N}_{2}$, without injecting any model tar, were run keeping all other operating conditions constant, in order to make sure that no compounds were formed within the char bed at high temperature.

For the experiments, the furnace temperature was first set to $1173 \mathrm{~K}$. The selected char had already experienced such high temperature in the gasifier from where it was collected, so no significant degradation of the char mass was expected (as confirmed also by the thermal degradation tests performed in nitrogen) and the effect of catalytic cracking on the mass (carbon deposition on the char bed surface, for instance) could be evaluated. The tests were repeated setting the furnace temperature to $1273 \mathrm{~K}$, in order to prove that at such high temperatures, the cracking of tar is mainly due to the thermal cracking effect rather than to the catalytic effect, and hence that lower temperatures are of more interest when trying to exploit the catalytic activity of gasification char.

At the beginning of each test, the whole line and reactor were flushed with $\mathrm{N}_{2}\left(0.03 \mathrm{~m}^{3} / \mathrm{h}\right)$ for $10 \mathrm{~min}$, then the furnace was switched on to reach the desired temperature at the highest heating rate possible (approximately $50 \mathrm{~K} / \mathrm{min}$ ), keeping the $\mathrm{N}_{2}$ flow constant. Given the flow and the volume of the char (bulk density $\rho=0.48 \mathrm{~g} / \mathrm{cm}^{3}$ ), a gas hourly space velocity (GHSV) of approximately $24,000 \mathrm{~h}^{-1}$ was kept constant in all tests. Once the furnace temperature stabilized, it was maintained for $40 \mathrm{~min}$. During this period of time no action was taken in the case of blank tests, while for tests with toluene the syringe pump was started, and $10 \mathrm{~cm}^{3}$ ( $8.67 \mathrm{~g}$ ) of toluene was injected into the main flow of $\mathrm{N}_{2}$, with a continuous flow of $4 \mathrm{~mm}^{3} / \mathrm{s}$ and a concentration of approximately $430 \mathrm{~g} / \mathrm{m}^{3}$. This value is significantly higher than concentrations typically occurring in real gasification processes, but it was selected in order to make the studied phenomenon more pronounced.

Empty reactor tests at the same furnace temperatures were also performed placing only quartz wool (no char bed) inside the reactor. Given the inertness of the quartz wool, the aim was to evaluate if part of the injected toluene was cracked inside the reactor due to the effect of the high temperatures involved, which is by thermal cracking reactions.

For each of the aforementioned tests, at the end of the injection period, the furnace was let to cool down to ambient temperature, the isopropanol from the impinger bottles was collected and sent for GC-FID analysis. Toluene and benzene, in particular, were identified and quantified from the chromatograms, but also other compounds could be detected. Once the concentration of the outlet toluene was determined, the total toluene collected could be determined, as well as the toluene removal efficiency of the selected char. The toluene removal efficiency $X$, expressed as a percentage, was calculated as the ratio of the amount of toluene removed during the process to the total amount injected during the test:

$$
X=\frac{m_{i}-m_{0}}{m_{i}} \cdot 100
$$


where $m_{i}$ is the mass of toluene injected in the reactor, while $m_{0}$ is the mass of toluene collected at the outlet of the reactor.

Table 1 summarizes the experimental tests carried out in the catalytic reactor and the respective operating conditions chosen.

Table 1. Experimental tests operating conditions. GHSV: Gas hourly space velocity.

\begin{tabular}{cccc}
\hline Tar Cracking Tests & Blank with Char Bed & Empty Reactor & With Char Bed \\
\hline Furnace & & $1173 \mathrm{~K}, 1273 \mathrm{~K}$ & \\
temperature & & $0.03 \mathrm{~m}^{3} / \mathrm{h}$ & \\
$\mathrm{N}_{2}$ feed flow & $0.6 \mathrm{~g}$ & n.a. & $0.6 \mathrm{~g}^{-1}$ \\
Char bed mass & $24,000 \mathrm{~h}^{-1}$ & n.a. & $24,000 \mathrm{~h}^{-1}$ \\
GHSV & n.a. & $8.67 \mathrm{~g}$ & $8.67 \mathrm{~g}$ \\
Toluene injected & & $40 \mathrm{~min}$ & \\
Test duration & & & \\
\hline
\end{tabular}

\section{Results and Discussion}

\subsection{Char Characterization}

The characteristics of the plant and of the char selected for the present study are reported in Table 2. In particular, the elemental composition (carbon, hydrogen, nitrogen, and sulphur content), the ash content, the moisture content, the specific surface area $S_{\mathrm{BET}}$, and the pore volume of the char are indicated. Moreover, the mineral composition of the ash was determined, and Table 3 reports the mass fractions of the most abundant elements. Other mineral species were detected but given their very low concentrations (lower than $0.20 \%$ ) they are not reported in the table. As it can be observed from the data, the ash of the selected char is rich in calcium $(17.47 \%)$ and contains smaller quantities of magnesium $(2.18 \%)$, iron $(1.12 \%)$, and other minor compounds (phosphorous, manganese, sodium, aluminum, sulphur, chromium, and barium). Alkali metals such as $\mathrm{Ca}, \mathrm{Mg}$, and $\mathrm{Na}$ are known to promote catalytic tar cracking reactions [39], together with K, which could not be found through ICP-OES analysis of the ash. The high calcium content of the selected char and its well-developed porosity might significantly contribute to its catalytic activity.

Table 2. Type of gasification technology and main properties of the char selected for the present study, partly taken from [22]. ICP-OES: Inductively-coupled plasma optical emission spectroscopy.

\begin{tabular}{clc}
\hline Plant Type & & Dual-Stage Gasifier \\
\hline Feedstock & & Woodchips \\
\hline & $\mathrm{C}$ & 78.97 \\
& $\mathrm{H}$ & 0.68 \\
Char Analysis $\left(\mathbf{\% w t}_{\mathrm{dry}}\right)$ & $\mathrm{N}$ & 0.20 \\
& $\mathrm{~S}$ & 0.31 \\
& $\mathrm{Ash}$ & 22.20 \\
\hline Moisture $\left(\% \mathrm{wt}_{\mathrm{as} \mathrm{received}}\right)$ & & 2.58 \\
$\mathrm{~S}_{\mathrm{BET}}\left(\mathrm{m}^{2} / \mathrm{g}\right)$ & & 587 \\
Pore volume $\left(\mathrm{cm}^{3} / \mathrm{g}\right)$ & & 0.30 \\
\hline
\end{tabular}


Table 3. Mineral composition of the ash of the selected gasification char, determined by means of ICP-OES analysis. Only the elements with mass fraction greater than $0.20 \%$ are reported.

\begin{tabular}{cc}
\hline Element & Mass Fraction (\%) \\
\hline $\mathrm{Ca}$ & 17.47 \\
$\mathrm{Mg}$ & 2.18 \\
$\mathrm{Fe}$ & 1.12 \\
$\mathrm{P}$ & 0.84 \\
$\mathrm{Mn}$ & 0.56 \\
$\mathrm{Na}$ & 0.40 \\
$\mathrm{Al}$ & 0.38 \\
$\mathrm{~S}$ & 0.37 \\
$\mathrm{Cr}$ & 0.30 \\
$\mathrm{Ba}$ & 0.22 \\
\hline
\end{tabular}

\subsection{Thermal Degradation Tests in $\mathrm{N}_{2}$ and in $\mathrm{CO}_{2}$}

The selected gasification char, as mentioned, was subjected to thermal degradation tests in a laboratory-scale tubular reactor. The present study focuses on the qualitative analysis of the gases produced during the thermal degradation process, rather than on its quantitative assessment. However, the residual mass values are hereby reported for completeness.

Tests in $\mathrm{N}_{2}$ showed that both at $973 \mathrm{~K}$ and at $1173 \mathrm{~K}$, no significant mass loss occurred, and $92.3 \%$ and $91.7 \%$ of the initial mass of char was measured at the end of the two tests, respectively, after $5 \mathrm{~h}$. This means that only $7.7 \%$ and $8.3 \%$ of the mass of char placed inside the reactor degraded during the tests. The mass loss observed during the tests is partly attributed to the removal of moisture, which accounts for $2.58 \%$ of the mass of char as received.

The gas composition trend at the outlet of the reactor and the temperature profile recorded inside the reactor during the tests in nitrogen at $973 \mathrm{~K}$ and $1173 \mathrm{~K}$ are shown in Figure 3.
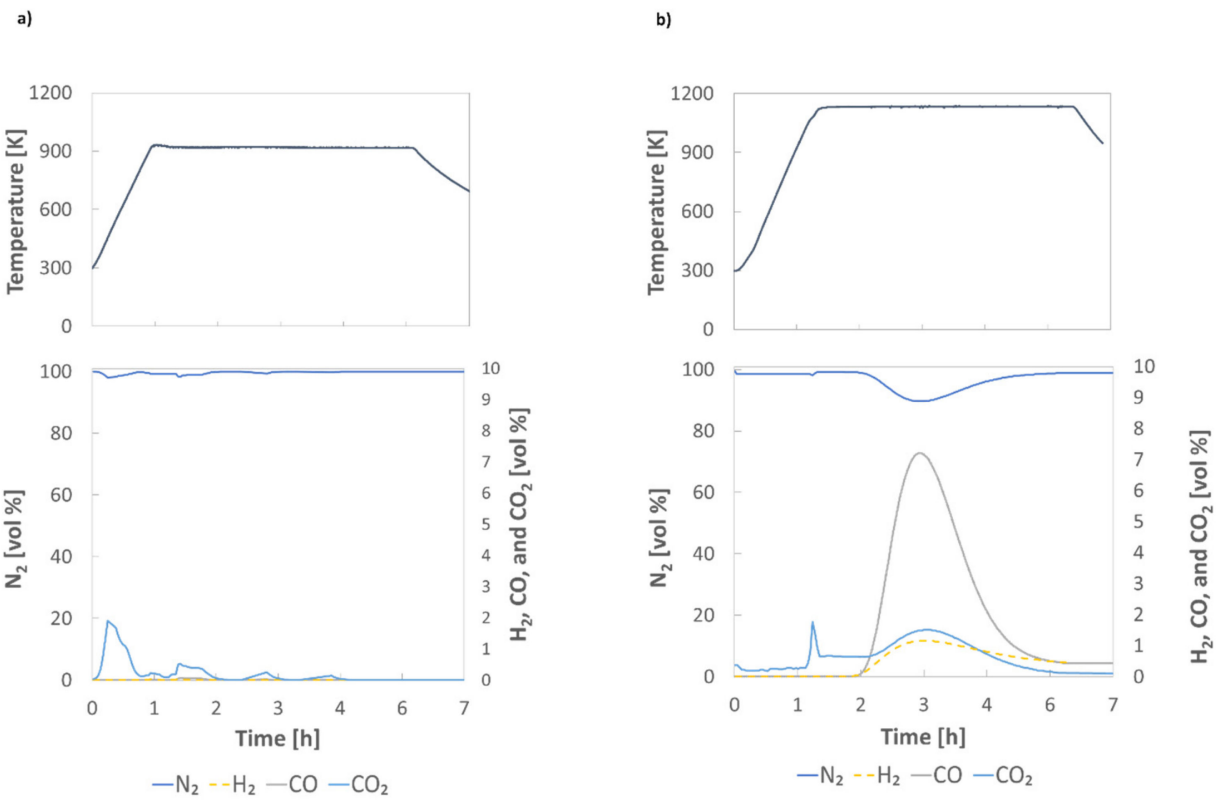

Figure 3. Test in $\mathrm{N}_{2}$ at (a) $973 \mathrm{~K}$ and (b) $1173 \mathrm{~K}$. Temperature profile inside the reactor and gas composition at the outlet $\left(\mathrm{N}_{2}, \mathrm{H}_{2}, \mathrm{CO}\right.$, and $\mathrm{CO}_{2}$ volumetric concentrations).

The analysis of the gases exiting the reactor shows that no significant changes in the outlet gas composition occurred in an inert atmosphere, especially at $973 \mathrm{~K}$, as a very small peak of $\mathrm{CO}_{2}(1.9 \%)$ occurs at the beginning of the heating process. Some hydrogen $\mathrm{H}_{2}$ and carbon monoxide $\mathrm{CO}$ are also detected in the outlet gas after the temperature plateau is reached, but their concentration is almost 
negligible, reaching a maximum of $0.4 \%$ and $0.7 \%$, respectively. During the test in nitrogen at $1173 \mathrm{~K}$, a small $\mathrm{CO}_{2}$ peak $(1.8 \%)$ is observed as the temperature rises, as well as a small peak of $\mathrm{H}_{2}(1.2 \%)$. In addition to this, after the temperature is stabilized, $\mathrm{CO}$ is produced, with a peak concentration in the outlet gas of $7.2 \%$. In both nitrogen tests, it is inferred that the moisture in the char, once evaporated, reacts with the carbon in the char, producing $\mathrm{CO}$ and $\mathrm{H}_{2}$, according to the water-gas reaction [14]:

$$
\mathrm{C}+\mathrm{H}_{2} \mathrm{O} \rightarrow \mathrm{CO}+\mathrm{H}_{2}
$$

Moreover, it is possible that $\mathrm{CO}_{2}$ and $\mathrm{CO}$ detected were produced by oxidation reactions occurring on the surface of the char or in its pore channels. In fact, as char is exposed to atmospheric air before starting the feed gas flow, oxygen molecules can be adsorbed within the porous structure of the char, chemically interact with it, and then be released as the heating proceeds [40].

It is necessary to point out that the gases released when using nitrogen as a carrier gas, although in very low concentrations, might also affect the catalytic performance of the char bed during tar removal tests.

Regarding the tests performed in carbon dioxide, at $973 \mathrm{~K}$ negligible char mass loss was observed after 5-h testing (around 3.4\%), even less than the mass loss occurring during the test in nitrogen at the same temperature conditions. However, as the furnace temperature is increased to $1173 \mathrm{~K}$, significant degradation of the char takes place in $\mathrm{CO}_{2}$ and the final residual mass of the char bed, after $5 \mathrm{~h}$, is only $33.7 \%$ of the initial mass. The results of the thermal degradation tests in terms of the residual mass of char, expressed as a percentage of its initial mass, are summarized in Table 4. It is important to notice that, even at the highest temperature (1173 K), the mass loss in $\mathrm{N}_{2}$ is very small, meaning that the material could easily withstand these conditions if used for gas cleaning purposes. The same applies in pure $\mathrm{CO}_{2}$ at $973 \mathrm{~K}$. However, increasing the temperature to $1173 \mathrm{~K}$ under $\mathrm{CO}_{2}$, the char experiences a significant increase in the mass loss. This latter result suggests adopting lower temperatures when using char for tar removal, given that real producer gas can contain a considerable share of $\mathrm{CO}_{2}$ and char could be quickly consumed.

Table 4. Char residual mass (as percentage of initial mass) after thermal degradation tests in pure $\mathrm{N}_{2}$ and in pure $\mathrm{CO}_{2}$, at 973 and $1173 \mathrm{~K}$.

\begin{tabular}{ccc}
\hline Temperature (K) & Feed Gas: $\mathbf{1 0 0} \boldsymbol{\%} \mathbf{~ N}_{\mathbf{2}}$ & Feed Gas: $\mathbf{1 0 0} \% \mathbf{C O}_{\mathbf{2}}$ \\
\hline 973 & $92.3 \%$ & $96.6 \%$ \\
1173 & $91.7 \%$ & $33.7 \%$ \\
\hline
\end{tabular}

The reason for such decrease in mass under reactive atmosphere is that $\mathrm{CO}_{2}$ gasification of char occurs, and carbon monoxide $\mathrm{CO}$ is produced from the carbon contained in the char and the carbon dioxide molecules, according to reverse Boudouard reaction, which is activated at high temperatures:

$$
\mathrm{C}+\mathrm{CO}_{2} \rightarrow 2 \mathrm{CO}
$$

Therefore, most of the mass lost in the process is due to the carbon that leaves the char to form $\mathrm{CO}$ molecules together with $\mathrm{CO}_{2}$. The phenomenon is further confirmed by the fact that the analysis of the outlet gas during the tests in $\mathrm{CO}_{2}$ shows a considerable amount of $\mathrm{CO}$ produced at $1173 \mathrm{~K}$ (Figure 4). $\mathrm{CO}$ production is observed also at $973 \mathrm{~K}$ in $\mathrm{CO}_{2}$ atmosphere. This is also due to $\mathrm{CO}_{2}$ reacting with the carbon in the char, but at this temperature, the reaction rate is much slower and, hence, the $\mathrm{CO}$ concentration is lower. 
a)

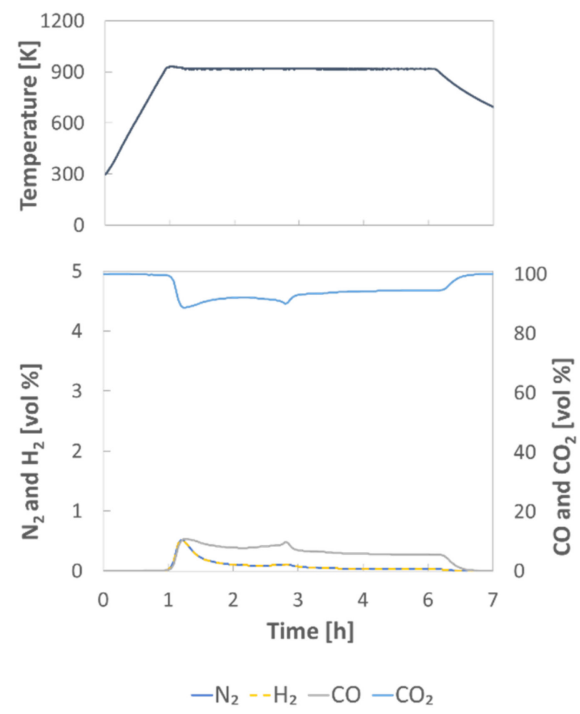

b)

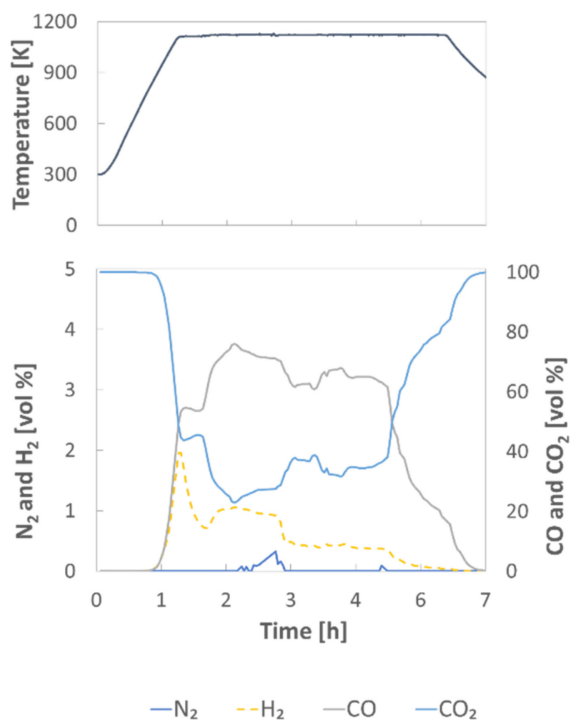

Figure 4. Tests in $\mathrm{CO}_{2}$ at (a) $973 \mathrm{~K}$ and (b) $1173 \mathrm{~K}$. Gas composition at the reactor outlet $\left(\mathrm{N}_{2}, \mathrm{H}_{2}, \mathrm{CO}\right.$ and $\mathrm{CO}_{2}$ volumetric concentrations).

The results of the tests in $\mathrm{CO}_{2}$ are all reported in the graphs in Figure 4. During the test at $973 \mathrm{~K}$, a peak of $\mathrm{CO}$ equal to $10.8 \%$ is reached initially, but then the $\mathrm{CO}$ concentration slowly decreases with time. In the test with $\mathrm{CO}_{2}$ at $1173 \mathrm{~K}$, on the other hand, the trend of $\mathrm{CO}$ production is very irregular. It shows a peak of $76.0 \%$ and a fast reduction towards the end of the test, when the temperature inside the reactor is still close to $1173 \mathrm{~K}$. The inhomogeneous carbonaceous structure of char might cause this uneven behavior. As during the tests in nitrogen, a small amount of $\mathrm{H}_{2}$ is also produced during the heating phase through the water-gas reaction. For $\mathrm{CO}_{2}$ tests, the hydrogen production reaches a peak concentration of $0.5 \%$ and $2.0 \%$ at $973 \mathrm{~K}$ and at $1173 \mathrm{~K}$, respectively.

\subsection{Tar Cracking Reactor Tests}

The tar cracking reactor was used to investigate the potential use of char for the cracking of toluene. First, tests were run without toluene injection (blank tests), by flowing pure $\mathrm{N}_{2}$ through the system and heating the char bed section of the reactor to 1173-1273 K. The results of these tests serve as a baseline for the subsequent tests with toluene, to verify that no tar compounds are released from the char just because it is treated in $\mathrm{N}_{2}$ at high temperature. The isopropanol collected at the end of each test from the impinger bottles at the outlet of the reactor was examined through GC-FID analysis and confirmed that no compounds were found other than the solvent. Hence, no condensable compounds were released from the char. The mass of the char placed inside the reactor was also measured before and after each test. The amount of mass loss during the blank tests was consistent with the previous experiments performed in the setup used for the study on thermal degradation. In fact, during the blank tests at $1173 \mathrm{~K}$ and at $1273 \mathrm{~K}$ the char lost $10.9 \%$ and $10.7 \%$ of the initial mass, respectively (comparable to the $8.3 \%$ of mass lost during the thermal degradation test in $\mathrm{N}_{2}$ at $1173 \mathrm{~K}$ ).

Toluene cracking tests with the same operating temperature and $\mathrm{N}_{2}$ flow were carried out by injecting toluene into the feed line once the furnace temperature stabilized at the desired temperature (either $1173 \mathrm{~K}$ or $1273 \mathrm{~K}$ ). Both empty reactor tests (without char bed, only quartz wool) and tests with char bed were run. At the end of each test, the content of the impinger bottles was first filtered, in case it contained some particulate, and then it was analyzed by the GC technique. The GC-FID analyses showed two major peaks identified as toluene and benzene, which could be quantified through calibration curves. Other minor peaks, at larger retention times, were found, but they were too small to be identified and quantified. Looking at the condensed compounds obtained from the different tests, 
shown in Figure 5, it can be visually noticed that not only toluene and benzene, which are colorless, were collected in the isopropanol solvent. From the appearance of the liquid collected during tests with toluene, it is in fact clear that some conversion reaction has occurred and other compounds other than toluene and benzene were released and condensed during the experiments. In particular, given their longer retention time and color, it is possible that the cracking of toluene led to the formation of larger aromatic hydrocarbons [41].

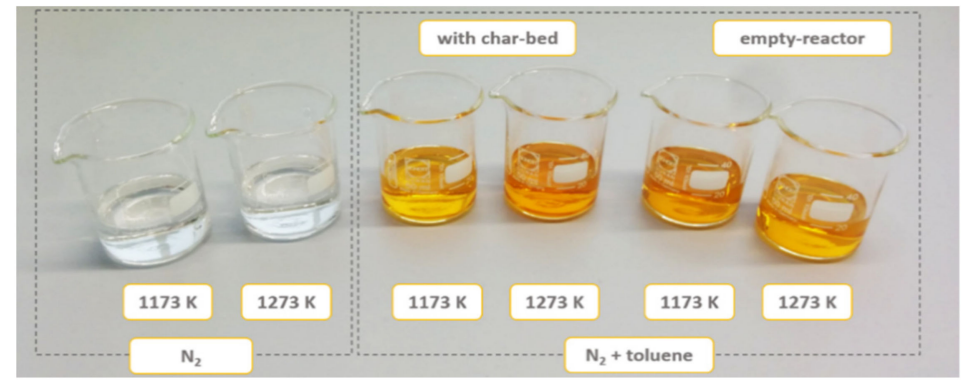

Figure 5. Condensable compounds diluted in isopropanol collected at the reactor outlet after tests with and without toluene at $1173 \mathrm{~K}$ and $1273 \mathrm{~K}$ (after filtration).

In the tests with the char bed, results from GC-FID analysis showed that at $1173 \mathrm{~K} 60.3 \%$ of the injected toluene was removed by cracking, whereas at $1273 \mathrm{~K}$ the toluene removal efficiency reached $99.0 \%$. Benzene, on the other hand, accounted for the $9.5 \%$ and $17.3 \%$ of the total toluene mass injected during the experiment at $1173 \mathrm{~K}$ and at $1273 \mathrm{~K}$, respectively.

Without the char bed, at $1173 \mathrm{~K}$ only $39.9 \%$ of the injected toluene was removed, while at $1273 \mathrm{~K}$ the toluene removal efficiency resulted to be equal to $97.3 \%$, almost as high as the one obtained under the same operating conditions with the char bed. On a mass basis, $7.88 \%$ of the injected toluene was converted into benzene at $1173 \mathrm{~K}$, whereas at $1273 \mathrm{~K}$ the benzene fraction was $22.5 \%$.

All the results of the tar cracking tests are reported in Table 5. The amount of toluene collected at the outlet of the reactor $\left(m_{0}\right)$ is indicated, as well as the toluene removal efficiency $(X)$. The last two lines of the table report the share of toluene converted into benzene and collected at the outlet of the reactor $\left(X_{\mathrm{b}}\right)$, and the share of toluene converted into coke and deposited on the bed $\left(X_{\mathrm{c}}\right) . X_{\mathrm{b}}$ and $X_{c}$, both expressed as a percentage, were calculated as the ratio of the mass of benzene collected and of the coke deposition, respectively, to the mass of toluene injected in the reactor $\left(m_{i}\right)$. The amount of coke deposition corresponds to the mass gain measured after each test (the difference between mass of the bed after the test and mass of the bed prior to the test).

Table 5. Results of empty reactor tests and tests with char bed. Total amount of toluene collected $m_{0}$, toluene removal efficiency $X$, share of toluene converted into benzene and collected at the outlet $X_{\mathrm{b}}$, and share of toluene deposited as coke on the bed $X_{C}$.

\begin{tabular}{cccccc}
\hline \multicolumn{2}{c}{ Tar Cracking Tests } & \multicolumn{2}{c}{ Empty Reactor } & \multicolumn{2}{c}{ With Char Bed } \\
\hline Temperature & $(\mathrm{K})$ & 1173 & 1273 & 1173 & 1273 \\
\hline$m_{0}$ & $(\mathrm{~g})$ & 5.21 & 0.23 & 3.44 & 0.08 \\
$X$ & $(\%)$ & 39.9 & 97.3 & 60.3 & 99.0 \\
$X_{\mathrm{b}}$ & $(\%)$ & 7.8 & 22.5 & 9.5 & 17.3 \\
$X_{\mathrm{c}}$ & $(\%)$ & 1.0 & 21.4 & 5.1 & 25.8 \\
\hline
\end{tabular}

The detection of different compounds in the isopropanol collected after empty reactor tests and the values of toluene removal efficiency obtained suggest that conversion of toluene is occurring in the reactor by thermal cracking when no catalyst is present. The thermal effect is less evident at $1173 \mathrm{~K}$, as $60.1 \%$ of the toluene injected into the system is collected at the outlet, while, as expected, it is accentuated at a higher temperature. In fact, at $1273 \mathrm{~K}$ only $2.7 \%$ of the inlet toluene is collected 
in the impinger bottles. The significant contribution of thermal cracking on the removal of toluene observed during the empty reactor tests implies that a major part of the high removal efficiency resulted in the test with char bed at $1273 \mathrm{~K}$ is due to the thermal effect. However, further comparing the results of the tests with and without the char bed it is evident that char actually plays a role in the removal of toluene from the gas, even at high temperature. Looking at the values of the toluene removal efficiencies obtained at $1173 \mathrm{~K}$, it emerges that the toluene removal efficiency resulting from the test with char is almost twice the toluene removal efficiency resulting from the empty reactor test. In other words, by using char, the amount of toluene collected at the outlet is almost half of the amount collected after the test in which only quartz wool was used, and this is due to the catalytic effect of char on toluene. At $1273 \mathrm{~K}$, the use of char increases the toluene removal efficiency from $97.3 \%$ to $99.0 \%$ with respect to the empty reactor test.

The results of the toluene removal efficiency can be compared with the results found in other studies. Mani et al. [42], for instance, compared toluene cracking through a bed of biochar and through an inert bed of ceramic beads. Testing temperatures in the range $873-1173 \mathrm{~K}$, they observed an increased toluene decomposition with increasing temperature, in the presence of biochar as well as in the presence of inert bed. For the selected space velocity $\left(2700 \mathrm{~h}^{-1}\right)$, at $1173 \mathrm{~K}$ they obtained very high toluene conversions: $94 \%$ in the presence of char and $62 \%$ in the presence of the inert bed (thermal cracking only), showing that biochar significantly increased the decomposition of toluene by acting as a catalyst. Bhandari et al. [43] used biochar from gasification of switchgrass and achieved a toluene removal of $78.65 \%$ at $973 \mathrm{~K}$ and of $81.01 \%$ at $1073 \mathrm{~K}$. Lower temperatures were tested by Korus et al. [44] using a coal-derived activated carbon for toluene conversion. They observed that below $1123 \mathrm{~K}$ negligible thermal effect is present and that when using the catalyst temperature has indeed a very significant impact on the conversion of the model tar. In fact, the toluene removal efficiency was reported to be as low as $16 \%$ at $923 \mathrm{~K}$ and grow above $90 \%$ at $1073 \mathrm{~K}$.

Considering the results reported in Table 5, it is worth highlighting that at $1173 \mathrm{~K}$ the char bed enhances both the cracking of toluene and the amount of benzene measured at the reactor outlet. At $1273 \mathrm{~K}$, on the other hand, although the presence of char leads to a higher toluene removal efficiency, the amount of benzene collected is higher for the empty reactor test. This might suggest that, at that temperature, the char acts as a catalyst promoting the cracking of benzene besides the cracking of toluene [45].

It was previously mentioned that condensed compounds collected with isopropanol were filtered before being sent for GC-FID analysis, because some very fine particulate matter was brought out of the reactor with the outflow gas. Mani et al. [42] suggest that, during cracking, toluene molecules can break and form coke depositing (solid carbon) on the char surface through the following reaction, which also leads to formation of hydrogen $\mathrm{H}_{2}$ :

$$
\mathrm{C}_{7} \mathrm{H}_{8} \rightarrow 7 \mathrm{C}(\mathrm{s})+4 \mathrm{H}_{2}
$$

The conversion of toluene during the experimental tests brought to the formation and deposition of coke on the surface of char, and some of it gathered in the condensed products as well. The deposition of coke on char because of toluene conversion also explains the fact that while in blank tests without toluene the mass of the char bed decreased during the tests, in all other cases an increase of the mass of the bed (either quartz wool and char or quartz wool only) was measured. The gain in mass is reported in Table 5 as a percentage of the amount of toluene injected into the system $\left(X_{\mathrm{c}}\right)$. The deposition of coke on the bed is not attributed to the conversion of toluene solely, but also to the cracking of the benzene [45] produced from toluene conversion. During the tests with char bed, the total mass of the bed increased by $35 \%$ (gaining $0.4 \mathrm{~g}$, that is $5.1 \%$ of the injected toluene) at $1173 \mathrm{~K}$, while at $1273 \mathrm{~K}$ it increased by $179 \%$ (gaining $2.2 \mathrm{~g}$, that is $25.8 \%$ of the injected toluene). This indicates that toluene and benzene were cracked on the surface of char and on the quartz wool placed below and above it, and a significant amount of coke, especially at a higher temperature, was deposited. An increase of coke production with increasing temperature was also observed by Song et al. [46] during cracking of 
tar from mallee wood pyrolysis over a bed of rice-straw char. A rise in the mass of the bed was also observed after empty reactor tests when no char was used. The mass of the quartz wool placed inside the reactor, in fact, increased by $15 \%$ (gaining $0.1 \mathrm{~g}$, that is $1.0 \%$ of the injected toluene) and threefold (gaining $1.9 \mathrm{~g}$, that is $21.4 \%$ of the injected toluene) at $1173 \mathrm{~K}$ and $1273 \mathrm{~K}$, respectively. This confirms a higher coke deposition at the higher temperature, and that coke was formed by both thermal cracking (in char bed tests as well as in empty reactor tests) and catalytic cracking (only in char bed tests). The significantly higher amount of coke deposition measured after the test with char at $1273 \mathrm{~K}$ supports the assertion that at that temperature the share of benzene $X_{\mathrm{b}}$ was lower with char than without char (17.3\% against $22.5 \%$ ) because of cracking of benzene leading to more coke deposition. The formation and deposition of carbon on the surface of char are of great concern when considering char for catalytic purposes. It is, in fact, well documented in the literature that coke gradually obstructs the pores of char and covers the active sites located on the surface, leading to a decrease in its microporous surface area and, eventually, to a decrease in its catalytic activity $[16,47,48]$. Long-duration tests should be carried out to evaluate the changes in the activity of char over time. However, as also pointed out by Ravenni et al. [49], since char is a by-product of the gasification process, it is continuously produced and available in the gasifier, so it could be easily and readily replaced once deactivated. In addition, it could even be recycled into the system and be gasified with the fresh feedstock.

Considering the reforming mechanisms that might occur on the surface of char, in [50,51], it is reported that, in the presence of $\mathrm{H}_{2}$, the cracking of toluene produces benzene and methane, according to Reaction (5):

$$
\mathrm{C}_{7} \mathrm{H}_{8}+\mathrm{H}_{2} \rightarrow \mathrm{C}_{6} \mathrm{H}_{6}+\mathrm{CH}_{4}
$$

If hydrogen molecules are produced through cracking of toluene into carbon coke and $\mathrm{H}_{2}$ (Reaction (4)) secondary reactions can be activated and toluene can further react with $\mathrm{H}_{2}$ to form benzene and methane. The benzene found in the condensed compounds at the outlet of the catalytic reactor suggests that both hydrogen and methane were produced from decomposition of toluene. However, the analysis of the gases produced during the process would be needed to evaluate the production of $\mathrm{H}_{2}$ and other permanent gases, like $\mathrm{CH}_{4}$, as the toluene passes through the catalytic reactor.

In [52], it is suggested that at temperatures higher than $1273 \mathrm{~K}$ the primary pathways of toluene conversion involve the formation of $\mathrm{H}$ and $\mathrm{CH}_{3}$ radicals through Reactions (6) and (7), alongside with benzyl $\left(\mathrm{C}_{6} \mathrm{H}_{5} \mathrm{CH}_{2}\right)$ and phenyl $\left(\mathrm{C}_{6} \mathrm{H}_{5}\right)$ radicals, respectively.

$$
\begin{gathered}
\mathrm{C}_{6} \mathrm{H}_{5} \mathrm{CH}_{3}=\mathrm{C}_{6} \mathrm{H}_{5} \mathrm{CH}_{2}+\mathrm{H} \\
\mathrm{C}_{6} \mathrm{H}_{5} \mathrm{CH}_{3}=\mathrm{C}_{6} \mathrm{H}_{5}+\mathrm{CH}_{3}
\end{gathered}
$$

The radicals $\mathrm{H}$ and $\mathrm{CH}_{3}$ can in turn attack toluene and accelerate its consumption through Reactions (8)-(10), which include the formation of benzene through demethylation (Reaction (9)) [52].

$$
\begin{gathered}
\mathrm{C}_{6} \mathrm{H}_{5} \mathrm{CH}_{3}+\mathrm{H}=\mathrm{C}_{6} \mathrm{H}_{5} \mathrm{CH}_{2}+\mathrm{H}_{2} \\
\mathrm{C}_{6} \mathrm{H}_{5} \mathrm{CH}_{3}+\mathrm{H}=\mathrm{C}_{6} \mathrm{H}_{6}+\mathrm{CH}_{3} \\
\mathrm{C}_{6} \mathrm{H}_{5} \mathrm{CH}_{3}+\mathrm{CH}_{3}=\mathrm{C}_{6} \mathrm{H}_{5} \mathrm{CH}_{2}+\mathrm{CH}_{4}
\end{gathered}
$$

The presence of the char influences significantly the toluene conversion pathways and, as previously discussed, enhances the cracking of toluene, but it is difficult to predict which reactions are favored. However, based on the results of this work, it is possible to infer that the selected char promotes the formation of gaseous compounds (most likely $\mathrm{H}_{2}$ and $\mathrm{CH}_{4}$ ) and coke, rather than of benzene, especially at $1273 \mathrm{~K}$. It is also possible that the coke formation process on the surface of char, which is more accentuated in the tests with char, partly inhibits the toluene to benzene formation, as these two are competing pathways [44]. 
Overall, the results obtained in this study are promising, since char from an existing commercial gasification plant, destined to be discarded as waste, was tested and proved to be suitable for tar catalytic cracking applications, giving high values of toluene conversion. It was also demonstrated that reaching very high temperatures on one hand, as suggested by the thermal degradation results, might cause the rapid consumption of the char bed, on the other hand, it is unnecessary for removal of toluene. In fact, at $1273 \mathrm{~K}$ the thermal cracking effect prevails over the catalytic one and the catalytic activity of the char bed remains underexploited. This is just a preliminary study, and further tests involving not only model tar toluene, but also real tar from a gasifier would be necessary. However, it is of interest that what is currently a waste product and a cost to gasification plants owners could eventually be efficiently used, as it is, for reducing the amount of tar in the producer gas, converting it into useful gaseous products.

\section{Conclusions}

In the present work, the potential use of char from biomass gasification for tar removal applications was assessed. Char with large surface area and large pore volume, was collected from a commercial gasification system installed in South-Tyrol (Italy) and used for thermal degradation and tar catalytic cracking tests.

First, the continuous analysis of gases exiting a lab-scale fixed-bed gasification reactor during char thermal degradation tests up to $1173 \mathrm{~K}$ in $\mathrm{N}_{2}$ and in $\mathrm{CO}_{2}$ was used to evaluate the production of gases in pyrolytic conditions (in $\mathrm{N}_{2}$, lowest char conversion) and in gas mixtures mainly composed of $\mathrm{CO}_{2}$ (maximum char conversion). In particular, the observed production of $\mathrm{CO}$ and of $\mathrm{H}_{2}$ might affect the activity of the char when used as a catalyst for tar removal, shifting equilibria. Catalytic cracking tests were performed for assessing the suitability of the selected char for the cracking of toluene in $\mathrm{N}_{2}$. The condensable compounds collected at the outlet of the catalytic reactor were analyzed by means of GC-FID analysis, for quantifying the amount of toluene that did not react in the process and the amount of benzene that was produced from toluene decomposition. At $1273 \mathrm{~K}$, a toluene removal efficiency of $99.0 \%$ was reached in the presence of char, but a similar result ( $97.3 \%$ toluene removal efficiency) was obtained in the empty reactor test, proving that at such high temperature the thermal cracking effect prevails. At $1173 \mathrm{~K}$, the catalytic activity of char is much more significant, increasing the toluene removal efficiency from $39.9 \%$ (empty reactor test) to $60.3 \%$. In all tests, toluene was partially converted into benzene and into coke (solid carbon), allegedly producing $\mathrm{H}_{2}$ and $\mathrm{CH}_{4}$ as well.

The analysis of the non-condensable gases at the reactor outlet would allow for a better understanding of the processes and reactions occurring inside the reactor. Moreover, the cracking of other model tar compounds and, successively, of real tar should be further investigated. Nevertheless, the results obtained so far confirm that char presents a very high catalytic activity in the process of toluene removal and that char collected as a residue from commercial gasifiers could be actually and efficiently used as it is for catalytic purposes.

Author Contributions: Conceptualization, E.C., F.P. and M.B.; Data curation, E.C.; Formal analysis, E.C.; Funding acquisition, F.P. and M.B.; Investigation, E.C.; Project administration, M.B.; Supervision, M.B.; Writing-original draft, E.C.; Writing—review \& editing, E.C., F.P. and M.B.

Funding: This research was funded by the Autonomous Province of Bolzano, Provincia Autonoma di Bolzano-Alto Adige, Ripartizione Diritto allo studio, Università e ricerca scientifica, through the NEXT GENERATION Project: "Novel EXTension of Biomass Poly-GENERATION to Small Scale Gasification Systems in South-Tyrol" (CUP B56J16000780003).

Conflicts of Interest: The authors declare no conflict of interest. The funders had no role in the design of the study; in the collection, analyses, or interpretation of data; in the writing of the manuscript, or in the decision to publish the results. 


\section{References}

1. Asadullah, M. Biomass gasification gas cleaning for downstream applications: A comparative critical review. Renew. Sustain. Energy Rev. 2014, 40, 118-132. [CrossRef]

2. Milne, T.A.; Evans, R.J.; Abatzaglou, N. Biomass Gasifier "Tars": Their Nature, Formation, and Conversion; National Renewable Energy Laboratory: Golden, CO, USA, 1998.

3. Hasler, P.; Nussbaumer, T. Gas cleaning for IC engine applications from fixed bed biomass gasification. Biomass Bioenergy 1999, 16, 385-395. [CrossRef]

4. Bridgwater, A.V. The technical and economic feasibility of biomass gasification for power generation. Fuel 1995, 74, 631-653. [CrossRef]

5. Baratieri, M.; Baggio, P.; Bosio, B.; Grigiante, M.; Longo, G.A. The use of biomass syngas in IC engines and CCGT plants: A comparative analysis. Appl. Therm. Eng. 2009, 29, 3309-3318. [CrossRef]

6. Hofmann, P.; Panopoulos, K.D.; Aravind, P.V.; Siedlecki, M.; Schweiger, A.; Karl, J.; Ouweltjes, J.P.; Kakaras, E. Operation of solid oxide fuel cell on biomass product gas with tar levels $>10 \mathrm{~g} \mathrm{Nm}^{-3}$. Int. J. Hydrog. Energy 2009, 34, 9203-9212. [CrossRef]

7. Rakesh, N.; Dasappa, S. Biosyngas for Electricity Generation Using Fuel Cells-A Gas Quality Assessment; ETA: Florence, Italy, 2018. [CrossRef]

8. Tijmensen, M.J.A.; Faaija, A.P.C.; Hamelinck, C.N.; van Hardeveldb, M.R.M. Exploration of the possibilities for production of Fischer Tropsch liquids and power via biomass gasification. Biomass Bioenergy 2002, 23, 129-152. [CrossRef]

9. Woolcock, P.J.; Brown, R.C. A review of cleaning technologies for biomass-derived syngas. Biomass Bioenergy 2013, 52, 54-84. [CrossRef]

10. Anis, S.; Zainal, Z.A. Tar reduction in biomass producer gas via mechanical, catalytic and thermal methods: A review. Renew. Sustain. Energy Rev. 2011, 15, 2355-2377. [CrossRef]

11. Aravind, P.V.; de Jong, W. Evaluation of high temperature gas cleaning options for biomass gasification product gas for Solid Oxide Fuel Cells. Progress Energy Combust. Sci. 2012, 38, 737-764. [CrossRef]

12. Simell, P.; Kurkela, E.; Ståhlberg, P.; Hepola, J. Catalytic hot gas cleaning of gasification gas. Catal. Today 1996, 27, 55-62. [CrossRef]

13. Myrén, C.; Hörnell, C.; Björnbom, E.; Sjöström, K. Catalytic tar decomposition of biomass pyrolysis gas with a combination of dolomite and silica. Biomass Bioenergy 2002, 23, 217-227. [CrossRef]

14. Sutton, D.; Kelleher, B.; Ross, J.R.H. Review of literature on catalysts for biomass gasification. Fuel Process. Technol. 2001, 73, 155-173. [CrossRef]

15. Nzihou, A.; Stanmore, B.; Sharrock, P. A review of catalysts for the gasification of biomass char, with some reference to coal. Energy 2013, 58, 305-317. [CrossRef]

16. Abu El-Rub, Z.; Bramer, E.A.; Brem, G. Review of Catalysts for Tar Elimination in Biomass Gasification Processes. Ind. Eng. Chem. Res. 2004, 43, 6911-6919. [CrossRef]

17. Dayton, D. Review of the Literature on Catalytic Biomass Tar Destruction; Milestone Completion Report; National Renewable Energy Lab.: Golden, CO, USA, 2002.

18. Devi, L.; Ptasinski, K.J.; Janssen, F.J.J.G.; van Paasen, S.V.B.; Bergman, P.C.A.; Kiel, J.H.A. Catalytic decomposition of biomass tars: Use of dolomite and untreated olivine. Renew. Energy 2005, 30, 565-587. [CrossRef]

19. Sun, Q.; Yu, S.; Wang, F.; Wang, J. Decomposition and gasification of pyrolysis volatiles from pine wood through a bed of hot char. Fuel 2011, 90, 1041-1048. [CrossRef]

20. Lee, J.; Kim, K.-H.; Kwon, E.E. Biochar as a Catalyst. Renew. Sustain. Energy Rev. 2017, 77, 70-79. [CrossRef]

21. Abu El-Rub, Z.; Bramer, E.; Al-Gharabli, S.; Brem, G. Impact of Char Properties and Reaction Parameters on Naphthalene Conversion in a Macro-TGA Fixed Char Bed Reactor. Catalysts 2019, 9, 307. [CrossRef]

22. Benedetti, V.; Patuzzi, F.; Baratieri, M. Characterization of char from biomass gasification and its similarities with activated carbon in adsorption applications. Appl. Energy 2018, 227, 92-99. [CrossRef]

23. Liu, Y.; Paskevicius, M.; Wang, H.; Parkinson, G.; Veder, J.-P.; Hu, X.; Li, C.-Z. Role of O-containing functional groups in biochar during the catalytic steam reforming of tar using the biochar as a catalyst. Fuel 2019, 253, 441-448. [CrossRef]

24. Fuentes-Cano, D.; Parrillo, F; Ruoppolo, G.; Gómez-Barea, A.; Arena, U. The influence of the char internal structure and composition on heterogeneous conversion of naphthalene. Fuel Process. Technol. 2018, 172, 125-132. [CrossRef] 
25. Vassilev, S.V.; Baxter, D.; Andersen, L.K.; Vassileva, C.G. An overview of the composition and application of biomass ash. Fuel 2013, 105, 19-39. [CrossRef]

26. Hu, M.; Laghari, M.; Cui, B.; Xiao, B.; Zhang, B.; Guo, D. Catalytic cracking of biomass tar over char supported nickel catalyst. Energy 2018, 145, 228-237. [CrossRef]

27. Abu El-Rub, Z.; Bramer, E.A.; Brem, G. Experimental comparison of biomass chars with other catalysts for tar reduction. Fuel 2008, 87, 2243-2252. [CrossRef]

28. Klinghoffer, N.B.; Castaldi, M.J.; Nzihou, A. Influence of char composition and inorganics on catalytic activity of char from biomass gasification. Fuel 2015, 157, 37-47. [CrossRef]

29. Qian, K.; Kumar, A. Reforming of lignin-derived tars over char-based catalyst using Py-GC/MS. Fuel 2015, 162, 47-54. [CrossRef]

30. Buentello-Montoya, D.A.; Zhang, X.; Li, J. The use of gasification solid products as catalysts for tar reforming. Renew. Sustain. Energy Rev. 2019, 107, 399-412. [CrossRef]

31. Dias, D.; Lapa, N.; Bernardo, M.; Godinho, D.; Fonseca, I.; Miranda, M.; Pinto, F.; Lemos, F. Properties of chars from the gasification and pyrolysis of rice waste streams towards their valorisation as adsorbent materials. Waste Manag. 2017, 65, 186-194. [CrossRef]

32. Ravenni, G.; Elhami, O.H.; Ahrenfeldt, J.; Henriksen, U.B.; Neubauer, Y. Adsorption and decomposition of tar model compounds over the surface of gasification char and active carbon within the temperature range 250-800 C. Appl. Energy 2019, 241, 139-151. [CrossRef]

33. Choi, C.; Shima, K.; Kudo, S.; Norinaga, K.; Gao, X.; Hayashi, J.-I. Continuous monitoring of char surface activity toward benzene. Carbon Resour. Convers. 2019, 2, 43-50. [CrossRef]

34. Patuzzi, F.; Prando, D.; Vakalis, S.; Rizzo, A.M.; Chiaramonti, D.; Tirler, W.; Mimmo, T.; Gasparella, A.; Baratieri, M. Small-scale biomass gasification CHP systems: Comparative performance assessment and monitoring experiences in South Tyrol (Italy). Energy 2016, 112, 285-293. [CrossRef]

35. Ahmad, J.; Rashid, U.; Patuzzi, F.; Baratieri, M.; Taufiq-Yap, Y.H. Synthesis of char-based acidic catalyst for methanolysis of waste cooking oil: An insight into a possible valorization pathway for the solid by-product of gasification. Energy Convers. Manag. 2018, 158, 186-192. [CrossRef]

36. Basso, D.; Patuzzi, F.; Gasparella, A.; Tirler, W.; Dal Savio, S.; Rizzo, A.M.; Chiaramonti, D.; Baratieri, M. Valorization Pathways for Char from Small Scale Gasification Systems in South-Tyrol: The Next Generation Project; ETA: Florence, Italy, 2017.

37. Cordioli, E.; Patuzzi, F.; Baratieri, M. Analysis of Biomass Chars Thermal Decomposition: Experimental Tests and Modelling in N2 and CO2 Atmosphere; ETA: Florence, Italy, 2017.

38. Zhang, Y.; Wu, W.; Zhao, S.; Long, Y.; Luo, Y. Experimental study on pyrolysis tar removal over rice straw char and inner pore structure evolution of char. Fuel Process. Technol. 2015, 134, 333-344. [CrossRef]

39. El-Rub, Z.Y. Biomass Char as an in-situ Catalyst for tar Removal in Gasification Systems; University of Twente: Enschede, The Netherlands, 2008.

40. Wang, H.; Dlugogorski, B.Z.; Kennedy, E.M. Coal oxidation at low temperatures: Oxygen consumption, oxidation products, reaction mechanism and kinetic modelling. Prog. Energy Combust. Sci. 2003, 29, 487-513. [CrossRef]

41. Raman, C.V.; Bhagavantam, S. The relation between colour and molecular structure in organic compounds. Indian J. Phys. 1929, 4, 57-78.

42. Mani, S.; Kastner, J.R.; Juneja, A. Catalytic decomposition of toluene using a biomass derived catalyst. Fuel Process. Technol. 2013, 114, 118-125. [CrossRef]

43. Bhandari, P.N.; Kumar, A.; Bellmer, D.D.; Huhnke, R.L. Synthesis and evaluation of biochar-derived catalysts for removal of toluene (model tar) from biomass-generated producer gas. Renew. Energy 2014, 66, 346-353. [CrossRef]

44. Korus, A.; Samson, A.; Szlęk, A.; Katelbach-Woźniak, A.; Sładek, S. Pyrolytic toluene conversion to benzene and coke over activated carbon in a fixed-bed reactor. Fuel 2017, 207, 283-292. [CrossRef]

45. Tamhankar, S.S.; Tsuchiya, K.; Riggs, J.B. Catalytic cracking of benzene on iron oxide-silica: Catalyst activity and reaction mechanism. Appl. Catal. 1985, 16, 103-121. [CrossRef]

46. Song, Y.; Zhao, Y.; Hu, X.; Zhang, L.; Sun, S.; Li, C.Z. Destruction of tar during volatile-char interactions at low temperature. Fuel Process. Technol. 2018, 171, 215-222. [CrossRef]

47. Burhenne, L.; Aicher, T. Benzene removal over a fixed bed of wood char: The effect of pyrolysis temperature and activation with $\mathrm{CO}_{2}$ on the char reactivity. Fuel Process. Technol. 2014, 127, 140-148. [CrossRef] 
48. Argyle, M.; Bartholomew, C. Heterogeneous Catalyst Deactivation and Regeneration: A Review. Catalysts 2015, 5, 145-269. [CrossRef]

49. Ravenni, G.; Sárossy, Z.; Ahrenfeldt, J.; Henriksen, U.B. Activity of chars and activated carbons for removal and decomposition of tar model compounds-A review. Renew. Sustain. Energy Rev. 2018, 94, 1044-1056. [CrossRef]

50. Jess, A. Mechanisms and kinetics of thermal reactions of aromatic hydrocarbons from pyrolysis of solid fuels. Fuel 1996, 75, 1441-1448. [CrossRef]

51. Song, E.; Song, J. Modeling of kerosene combustion under fuel-rich conditions. Adv. Mech. Eng. 2017, 9, 168781401771138. [CrossRef]

52. Zhang, L.; Cai, J.; Zhang, T.; Qi, F. Kinetic modeling study of toluene pyrolysis at low pressure. Combust. Flame 2010, 157, 1686-1697. [CrossRef]

(C) 2019 by the authors. Licensee MDPI, Basel, Switzerland. This article is an open access article distributed under the terms and conditions of the Creative Commons Attribution (CC BY) license (http://creativecommons.org/licenses/by/4.0/). 